\title{
Quantificação da Transmissão de Fusarium moniliforme de Sementes para Plântulas de Milho
}

\author{
Andrea Flavia Sartori ${ }^{1 *}$, Erlei Melo Reis ${ }^{1 * *}$ \& Ricardo Trezzi Casa ${ }^{2}$ \\ ${ }^{1}$ Universidade de Passo Fundo, Faculdade de Agronomia e Medicina Veterinária, Passo Fundo, RS, e-mail: \\ andrea.sartori@ pantec.zzn.com; ${ }^{2}$ Prof. Dr. Fitopatologista, CAV/UDESC, Lages, SC
}

(Aceito para publicação em 03/02/2004)

Autor para correspondência: Andrea Flavia Sartori

SARTORI, A.F., REIS, E.M. \& CASA, R.T. Quantificação da transmissão de Fusarium moniliforme de sementes para plântulas de milho. Fitopatologia Brasileira 29:456-458. 2004.

\begin{abstract}
RESUMO
O fungo Fusarium moniliforme (sin. F. verticillioides) é o principal patógeno associado a sementes de milho (Zea mays) no Brasil. $\mathrm{O}$ fungo pode ser introduzido pelas sementes em áreas isentas, causando deterioração de sementes, morte de plântulas, podridão radicular, do colmo e da espiga. Com o objetivo de quantificar sua transmissão para as plântulas de milho, foi conduzido um experimento em casa de vegetação utilizando-se sementes do híbrido AG-9020 sem tratamento com fungicida e com incidência natural média de $46 \%$. Realizou-se a semeadura em 04/09/2001, em caixas de madeira contendo substrato isento do fungo constituído pela mistura de solo de horizonte "B", areia grossa e vermiculita na proporção de 3:1:1. As avaliações do número de plantas emersas e a transmissão do fungo foram realizadas aos 15, 30 e 45 dias após a semeadura. Em cada

época, coletaram-se, ao acaso, 200 plântulas. As plantas foram lavadas e levadas ao laboratório. De cada planta destacou-se o tegumento remanescente da semente, a raiz primária, o entrenó subcoronal, o coleóptilo e a base das folhas. Após, realizou-se a assepsia do material em hipoclorito de sódio (1\%) por $3 \mathrm{~min}$, seguido de lavagem com água esterilizada e plaqueamento em meio $1 / 4$ de batata-sacarose-ágar. Os resultados indicaram que o fungo foi detectado em todos os órgãos da plântula isolados e nas três épocas de avaliação. O percentual médio de transmissão foi de 46,$1 ; 34,9 ; 23,6 ; 7,2$ e $14,6 \%$, respectivamente, para o tegumento remanescente da semente, raiz primária, entrenó subcoronal, coleóptilo e base das folhas.

Palavras-chave adicionais: fonte de inóculo, patologia de semente, Zea mays.
\end{abstract}

\section{ABSTRACT}

Transmission of Fusarium moniliforme from seeds to corn seedlings

The fungus Fusarium moniliforme (sin. F. verticillioides) is the principal pathogen associated with corn (Zea mays) seed in Brazil. The fungus may be introduced to new free pathogen growing areas causing seed decay, seedling blight, root rot, stalk and ear rot. This experiment was carried out in the greenhouse at FAMV/UPF using seed of corn hybrid AG-9020 with and without seed treatment and with a fungus incidence of $46 \%$. The goal was to quantify the fungus transmission from seeds to seedlings. Seeding was performed on September $9^{\text {th }}, 2001$, in aluminum trays and a wooden frame containing a substratum free from the fungus. Substratum was a mixture of soil horizon "B", course sand and vermiculite in the proportion $3: 1: 1$. Number of emerged seedlings and fungus transmission were counted and evaluated at 15, 30 and 45 days after sowing. At each time, 200 seedlings were randomly sampled. Seedlings were washed and taken to the laboratory. From each remaining seedling seed husk, seminal roots, subcrown internode, coleoptyle and leaf base tissue were detached. Tissues desinfestation with $50 \%$ sodium hipochloride $(2 \%)$ for $3 \mathrm{~min}$, followed by rinsing with sterile water were performed and plated on potato sucrose agar. The fungus was detected in isolation in all seedling parts and in the three sampling times. The mean percentage of transmission was 46.1; $34.9 ; 23.6 ; 7.2$ and $14.6 \%$, respectively, for the remaining seed tegument, seminal roots, subcrown internode, coleoptyle and leaves bases.
A cultura do milho (Zea mays L.) tem um grande papel econômico e social no país ocupando uma área cultivada, na safra 2002/03, no Brasil em torno de 9,382 milhões de hectares e, no Rio Grande do Sul, de 1.401.600 hectares. O rendimento médio no Brasil é de $3.290 \mathrm{~kg} \cdot \mathrm{ha}^{-1}$ e, no estado do Rio Grande do Sul, de 3.500 kg.ha- ${ }^{-1}$ (Conab, 2003).

Segundo Barba (2001), a grande maioria dos parasitas necrotróficos utiliza-se da semente como veículo de disseminação, abrigo e meio de sobrevivência.

Alguns autores afirmam que a semente infetada

*Bolsista da Capes

**Bolsista do CNPq introduz os parasitas necrotróficos nas áreas de cultivo (Reis \& Casa, 1996; Pinto, 1996; Zambolim et al., 2000). Por essa razão, são consideradas importantes fontes de inóculo (Maude, 1988), podendo interferir na densidade populacional e no rendimento de grãos, por causar podridão de sementes, morte de plântulas, podridão de raízes e da base do colmo (Reis \& Casa, 1996; Casa et al., 1998; White, 1999).

No Brasil, os principais fungos patogênicos veiculados pelas sementes de milho são Fusarium moniliforme (Sheld.), Diplodia maydis (Berk.) Sacc. e F. graminearum Schwabe (Tanaka \& Balmer, 1980; Gomes et al., 1981; Luz, 1997). Dentre os patógenos associados às sementes, $\mathrm{o} F$. moniliforme 
Quantificação da transmissão de Fusarium moniliformede sementes para...

[sin. F. verticillioides (Sacc.) Nirenberg] é o mais comumente encontrado (Reis et al., 1995; Reis \& Casa, 1996). Deve-se ressaltar que os fungos $F$. moniliforme, $F$. graminearum, Diplodia maydis e D. macrospora Earle causam podridões da base do colmo (PBC) e podridões de espiga (White, 1999). As $\mathrm{PBC}$ são consideradas as doenças mais importantes à cultura do milho em razão dos danos que causam (Reis \& Casa, 1996). Para seu controle, dever-se-ia procurar eliminar ou reduzir o inóculo nas suas principais fontes, ou seja, em sementes e restos culturais.

Muitos fungos associados às sementes de milho podem ser transmitidos às plântulas (McGee, 1988; Casa, 2000). Porém, a taxa de transmissão, por exemplo, de F. moniliforme, mesmo com as sementes apresentando altas incidências deste fungo, ainda não foi quantificada.

O objetivo principal deste trabalho foi quantificar a transmissão do fungo $F$. moniliforme das sementes para diferentes órgãos das plântulas de milho: tegumento remanescente da semente, raiz primária, entrenó subcoronal, coleóptilo e a base das folhas.

Esta ação de pesquisa foi realizada em laboratório e em casa de vegetação na Faculdade de Agronomia e Medicina Veterinária da Universidade de Passo Fundo, FAMV/UPF, nos meses de setembro e outubro de 2001, não foi repetida no tempo.

Utilizaram-se sementes do híbrido AG-9020, com uma incidência natural de $F$. moniliforme de $46 \%$, sem ter recebido tratamento com fungicidas. Realizou-se a semeadura em 04/ 09/2001, em 12 recipientes de $41 \mathrm{~cm}$ de comprimento x 28 $\mathrm{cm}$ de largura x $10 \mathrm{~cm}$ de altura, encaixados em bandejas de alumínio de $46 \mathrm{~cm}$ de comprimento x $31 \mathrm{~cm}$ de largura x $5 \mathrm{~cm}$ de altura, contendo substrato isento do fungo constituído pela mistura de solo de horizonte "B", areia grossa e vermiculita, na proporção de 3:1:1. Em cada recipiente semearam-se 50 sementes. $\mathrm{O}$ substrato foi umedecido com água $24 \mathrm{~h}$ antes de se efetuar a semeadura com água da torneira. Realizaram-se, no substrato de cada caixa, 50 orifícios de $5 \mathrm{~cm}$ de profundidade e $0,7 \mathrm{~cm}$ de diâmetro com um bastão de vidro, em cada um dos quais foi colocada uma semente. A umidade do solo foi mantida na capacidade de campo e a irrigação foi feita por absorção de água pelo substrato através da lateral da bandeja. Foram preparados 12 recipientes de modo a procederse às avaliações em três épocas.

Em cada época, aos 15, 30 e 45 dias após a semeadura, coletaram-se ao acaso 200 plântulas. A retirada das plântulas do solo foi realizada cuidadosamente, de modo a causar o mínimo de danos em seus órgãos. As plântulas foram lavadas em água corrente para retirada do excesso de solo aderido ao sistema radicular e levadas ao laboratório. De cada planta, destacaram-se o tegumento remanescente da semente, a raiz primária, o entrenó subcoronal, o coleóptilo e a base das folhas. Após, realizou-se a assepsia do material em hipoclorito de sódio (1\%) por $3 \mathrm{~min}$, seguido de lavagem com água esterilizada. Os tecidos vegetais foram plaqueados em placas de Petri plástica (previamente esterilizadas com aldeído fórmico, durante $72 \mathrm{~h}$ ), com $8,5 \mathrm{~cm}$ de diâmetro, contendo meio de cultura $1 / 4$ de BSA ( $50 \mathrm{~g}$ de batata, $5 \mathrm{~g}$ de sacarose e $15 \mathrm{~g}$ de ágar para cada litro de meio de cultura), acrescido de antibiótico (sulfato de estreptomicina $0,02 \mathrm{~g} \mathrm{em} 50 \mathrm{ml}$ de água destilada-esterilizada) após autoclavagem e quando o meio de cultura encontrava-se à temperatura de aproximadamente $50^{\circ} \mathrm{C}$. O material foi incubado durante nove dias em câmara de crescimento a temperatura de $25^{\circ} \mathrm{C} \pm 2{ }^{\circ} \mathrm{C}$ e fotoperíodo de $12 \mathrm{~h}$. Considerou-se infetado o órgão onde foi possível identificar a colônia e/ou estruturas do fungo sob lupa binocular (Zeiss com aumento de 50x).

Os dados foram expressos em percentagem de transmissão do fungo da semente para cada órgão em função da incidência do fungo na semente e da incidência no órgão ou tecido em função do tempo após a semeadura.

$O$ fungo $F$. moniliforme foi detectado, através dos isolamentos, em todos os órgãos das plântulas e nas três épocas de avaliação (Tabela 1).

O percentual médio de transmissão nas três épocas foi de 46,$1 ; 34,9 ; 23,6 ; 7,2$ e $14,6 \%$, respectivamente, para o tegumento remanescente da semente, raiz primária, entrenó subcoronal, coleóptilo e base das folhas.

A semente pode ser fonte de inóculo para as podridões da base do colmo (Reis \& Casa, 1996; Zambolim et al., 2000), porém, para se demonstrar isso, as plantas deveriam ser conduzidas até o final do ciclo, o que não foi feito no presente trabalho. Sendo a semente fonte de inóculo, dever-se-ia controlar o fungo com fungicidas. Por outro lado, como $F$. moniliforme ataca vários hospedeiros, como, por exemplo, arroz, cana-de-açúcar e sorgo, além do milho (Booth, 1971). No presente trabalho deu-se o primeiro passo nessa direção e, numa segunda etapa, dever-se-á conduzir o trabalho até o estádio de plantas adultas, avaliando-se as podridões da base do colmo.

Detectou-se a presença do fungo em órgãos radiculares o que poderia causar podridão radicular e PBC. Diversos

TABELA 1 - Percentagem de transmissão de Fusarium moniliforme de sementes para plântulas de milho (Zea mays) aos 15,30 e 45 dias após a semeadura

\begin{tabular}{lccccc}
\hline \hline Dias após a & \multicolumn{5}{c}{ Incidência (\%) } \\
\cline { 2 - 6 } semeadura & Tegumento & Raiz primária & Entrenó subcoronal & Coleóptilo & Base das folhas \\
\hline 15 & 56,9 & 55,4 & 23,1 & 6,1 & 3,1 \\
30 & 19,2 & 26,2 & 26,9 & 6,9 & 16,9 \\
45 & 62,3 & 23,1 & 20,8 & 8,5 & 23,8 \\
\hline Média & 46,1 & 34,9 & 23,6 & 7,2 & 14,6 \\
\hline
\end{tabular}




\section{A.F. Sartori et al.}

autores têm citado que $F$. moniliforme causa podridão radicular em milho (Reis \& Casa, 1996; Dodd \& White, 1999; Fernandes \& Oliveira, 2000). Logicamente, pela evolução da doença, crescimento do micélio, colonizando os tecidos radiculares, atingirá o entrenó subcoronal, a coroa e os primeiros nós do colmo. Nessa fase, a descoloração ocorre próxima à maturação fisiológica da cultura e a doença recebe o nome comum de podridão da base do colmo.

$O$ fungo $F$. moniliforme pode, saprofiticamente, manterse no tegumento remanescente das sementes, pois se trata de um fungo de solo como descrito por (Booth, 1971), e sobrevive em restos culturais.

À semelhança do que se demonstrou com a transmissão de $F$. moniliforme, o mesmo deve ocorrer com $D$. maydis, $D$. macrospora e F. graminearum. Casa (1997) mostrou essa possibilidade para $D$. maydis.

Pode-se concluir que $F$. moniliforme a partir de sementes de milho naturalmente infetadas é transmitido para diferentes órgãos da planta até 45 dias após a semeadura.

\section{REFERÊNCIAS BIBLIOGRÁFICAS}

BARBA, J.T. Bipolaris sorokiniana (Cochliobolus sativus) em sementes de cevada: detecção, transmissão e controle. 2000. Dissertação (Mestrado em Agronomia/Fitopatologia). Universidade de Passo Fundo, Passo Fundo, 2001.

BOOTH, K.J. The Genus Fusarium. Kew, Surrey, C.M.I., 1971.

CASA, R.T. \& CASA, R.T. Diplodia maydis e Diplodia macrospora associados à semente de milho. (Dissertação de Mestrado) Departamento de Fitopatologia. Viçosa. Universidade Federal de Viçosa, 1997.

CASA, R.T. Sobrevivência de Stenocarpella maydis e Stenocarpella macrospora em restos culturais de milho. 2000. (Tese de Doutorado) Departamento de Fitopatologia. Viçosa. UFV, 2000.

CONAB-Disponívelem:<http://www.conab.gov.br/politica_agricola/ safra/quadro7.xls>. Acesso em: 06 jan. 2003.

FERNANDES, F.T. \& OLIVEIRA, E. de. Principais doenças na cultura do milho. Sete Lagoas: EMBRAPA - CNPMS, Circular técnica, 26. 2000.

GOMES, J., CARVALHO, A.O.R. \& NAZARENO, N.R.X. Avaliação estadual de cultivares de milho. Londrina, IAPAR, Informe de pesquisa, 40. 1981.

LUZ, W.C. da. Tratamento de sementes de milho com fungicidas. Passo Fundo: Embrapa-CNPT, Circular Técnica, 7. 1997.

MAUDE, R.B. Achievements and objectives in research on seed-borne diseases of vegetables. In: Nasser, L.C., Wetzel, M.M. \& Fernandes. J.M. (Eds.) Proceedings; Seed Pathology International Advanced Icourse. Brasília, ABRATES, 1988. Part 4, p. 267-275.

McGEE, D.C. Maize diseases: a reference source for seed technologists. St. Paul: The American Phytopathological Society. 1988.

REIS, A.C., REIS, E.M., CASA, R.T. \& FORCELINI, C.A. Erradicação de fungos patogênicos associados a sementes de milho e proteção contra Pythium spp. presente no solo pelo tratamento com fungicidas. Fitopatologia Brasileira 20:585-590. 1995.

REIS, E.M. \& CASA, R.T. Manual de identificação e controle de doenças de milho. Passo Fundo: Aldeia Norte, 1996

REIS, E.M., CASA, R.T. \& MEDEIROS, C.A. Diagnose, patometria e controle de doenças de cereais de inverno. Londrina: MC Gráfica Ltda. 2001.

WHITE, D.G. Compendium of corn diseases. Third Edition St. Paul: The American Phytopathological Society, 1999.

ZAMBOLIM, L., CASA, R.T. \& REIS, E.M. Sistema plantio direto e doenças em plantas. Fitopatologia Brasileira 25:585-595. 2000. 